\title{
Development and stagnation of the last Pleistocene icecap in the Yellowstone Lake Basin, Yellowstone National Park, USA')
}

\author{
by Gerald M. Richmond, Denver, U. S. Geological Survey
}

With 3 figures

A b t ract. In late Pleistocene (Pinedale) time, the last of a series of Pleistocene icecaps developed in the Yellowstone Lake Basin. Initiated by a large glacier that entered the lake basin from the upper valley of the Yellowstone River, the icecap gradually thickened until, at the glacial maximum, it had a maximum thickness of about $925 \mathrm{~m}$, covered about $6,200 \mathrm{~km}^{2}$, and comprised about $975 \mathrm{~km}^{3}$ of ice. The cap overrode the basin divides in all directions, including the high crest of the Absaroka Range to the east.

After the maximum, the ice receded and then readvanced before stagnation set in. A sequence of discontinuous kame terraces record the gradual stagnation of the ice from a height of $280 \mathrm{~m}$ above the present level of Yellowstone Lake $(2,360 \mathrm{~m}$ altitude) down to $33 \mathrm{~m}$ above the present lake, at which time the icecap was entirely surrounded by water. An ancestral Yellowstone Lake began to form at a height of $180 \mathrm{~m}$ above the present lake level northeast of the icecap and opened gradually southwestward into the basin at successively lower levels against the receding ice margin. It became an open body of water $21 \mathrm{~m}$ above present lake level about 11,000 years ago when the ice disappeared entirely.

$\mathrm{Z}$ us a m menfassung. Während des Jungpleistozäns (Pinedale) stieß als letztes Glied einer Serie von Vergletscherungen ein großer Gletscher aus der südlichen Absaroka-Range durch das hochgelegene Tal des Yellowstone River in nordwestlicher Richtung in das Seebecken vor. Während des Maximalstandes nahm der Gletscher $6200 \mathrm{~km} 2$ ein; seine größte Mächtigkeit betrug etwa $925 \mathrm{~m}$, so daß sich die gesamte Eismasse auf etwa $975 \mathrm{~km}^{3}$ belaufen haben dürfte. Das Eis überschritt den Rand des Beckens in allen Richtungen und gelangte in die benachbarten Täler, auf die angrenzenden Plateaus und Gebirgsränder, die ebenfalls Eiskappen aufwiesen. Eine Verzahnung des Hauptgletschers mit den Lokalgletschern ist an mehreren Stellen nachzuweisen.

Nach dem Maximum des Vorstoßes taute der Gletscher teilweise ab, um später erneut vorzurücken, jedoch nicht bis zum Maximalstand. Der dann einsetzende Abtauprozeß, der in mehreren Phasen erfolgte, ist durch eine Folge von nicht zusammenhängenden Rückzugsbildungen (Kames-Terrassen, See- und Beckenabsätze) zwischen 280 und $33 \mathrm{~m}$ über dem jetzigen Seespiegel $(2360 \mathrm{~m})$ markiert. In einer Höhe von $180 \mathrm{~m}$ begann sich nordöstlich der abtauenden Eismasse zum ersten Mal ein Ur-Yellowstone-See zu bilden, der sich bei ständig sinkendem Wasserspiegel durch den zurückweichenden Eisrand allmählich in südwestlicher Richtung vergrößerte. Vor etwa 11000 Jahren, als das Eis vollständig verschwand, bildete sich $21 \mathrm{~m}$ über dem heutigen Seespiegel zum ersten Mal ein See mit offener Wasserfläche.

\section{Introduction}

Yellowstone National Park, located south of the $45^{\circ}$ parallel of latitude, mostly in northwestern Wyoming, encompasses a broad volcanic plateau at an altitude of about $2,500 \mathrm{~m}$. To the west, this plateau descends about $700 \mathrm{~m}$ to the Snake River Plain. To the north, east and south the plateau is surrounded by mountains (Figure 1) that rise as much as $1,000 \mathrm{~m}$ above it. The plateau is made up of lower and middle Pleistocene welded tuffs and rhyolite flows (Boyd 1961, Christiansen, Obradovich and Blank 1968). Structurally, the plateau lies at the intersection of the northeast-trending downwarp of the Snake River Plain - underlain by upper Cenozoic volcanic rocks - with several north- and northwest trending fault block mountains - underlain by Precambrian crystalline rocks and Palezoic and Mesozoic sedimentary rocks. In the eastern part of the Park is the Absaroka Range, made up predominantly of andesitic volcanic sediments and lava flows of Eocene and Oligocene age (Prostka 1968).

1) Publication authorized by the Director, U. S. Geological Survey. 


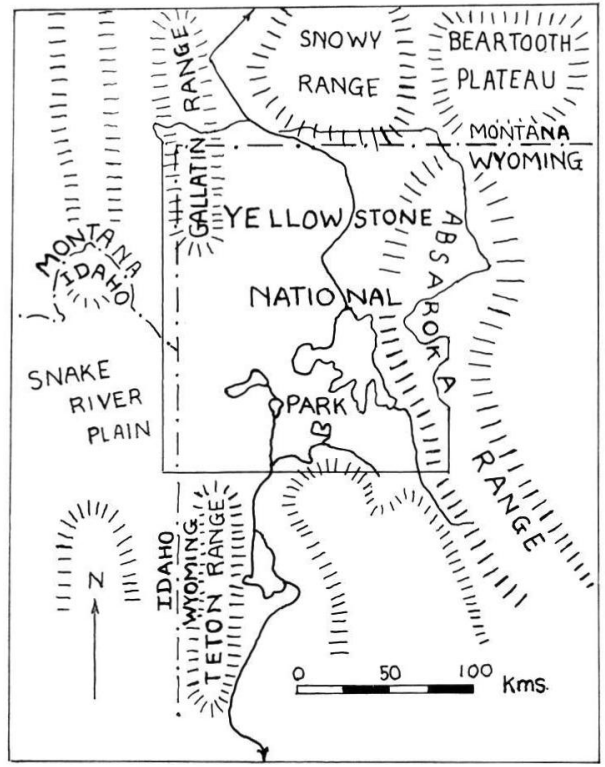

Fig. 1. Index map showing location of Yellowstone National Park and adjacent features mentioned in text.

Yellowstone Lake Basin, in the south-central part of the Park, is bordered on the south and east by the Eocene volcanic rocks of the Absaroka Range, and is irregularly filled to the north and west by Quaternary rhyolite tuffs and flows. The basin contains Yellowstone Lake, one of the largest bodies of water in the western United States. Yellowstone River enters the lake from the south through a broad canyon which heads high in the Absaroka Range to the southeast, and flows northward out of the lake through the famous Grand Canyon of the Yellowstone River, locally $400 \mathrm{~m}$ deep.

\section{Older Pleistocene glaciations}

Evidence of three early and middle Pleistocene glaciations - from oldest to youngest, the Washakie Point, Cedar Ridge, and Sacagawea Ridge Glaciations - has been found in several ranges of the Rocky Mountains (RICHMOND 1957, 1965). Their type deposits are in the Wind River Mountains, only $130 \mathrm{~km}$ from Yellowstone National Park (RicHMOND 1962, 1964). These glaciations are considered to be correlative with the Nebraskan, Kansan, and Illinoian Glaciations, respectively, of the U. S. continental interior (RICHMOND 1957). In Yellowstone Park, deposits of only one of these glaciations, believed to represent the youngest or Sacagawea Ridge Glaciation, have been found. It is possible that the lower and middle Pleistocene rhyolite tuffs and flows may conceal deposits of the earlier glaciations.

In early late Pleistocene time, the Bull Lake Glaciation, of early Wisconsinan age, formed a thicker and more extensive icecap in the Yellowstone Lake basin than that formed during the last or Pinedale Glaciation of late Wisconsinan age, with which this paper is principally concerned. The oldest deposits of the Bull Lake Glaciation rest on a rhyolite flow that has an age of 150,000 years B. P. (Potassium-argon dating by J. D. OBRADOVICH, written commun. 1968). The age of a second advance of this glaciation, as determined from the estimated rate of hydration and thickness of hydration rims along fractures in obsidian pebbles from end moraines, is $80,000 \pm 20,000$ years (IRVING 
Friedman, written commun. 1967). Wood from recessional lake deposits of this glaciation yields a radiocarbon age of $>42,000$ years B. P. (W-2197) (MEyer Rubin, written commun. 1968).

\section{Development of the last Pleistocene icecap}

About 25,000 years ago, in late Pleistocene time, during the Pinedale Glaciation of late Wisconsinan age, a complex of related icecaps formed in and near Yellowstone National Park: in the Yellowstone Lake Basin itself, in the Wind River Mountains to the south, in the high parts of the Absaroka Range to the southeast, in the Snowy Range and drainage of the Lamar River to the north, on the Beartooth Plateau to the northeast, and on the Pitchstone Plateau in the southwestern part of the Park. Valley glaciers formed in neighboring ranges above $3,000 \mathrm{~m}$ in altitude. Late Pleistocene orographic snowline, taken as the median altitude between terminal moraines and the highest points on cirque headwalls in the region, was about $2,500 \mathrm{~m}$.

In the Absaroka Range east of Yellowstone Lake, small glaciers formed in the cirques and began to advance westward down the valleys toward the lake. Southeast of the lake, valley glaciers from the higher part of the Absaroka Range coalesced in the broad deep upper valley of the Yellowstone River to form a single large glacier which flowed into Yellowstone Lake Basin. The lower end of this glacier appears to have served as a nucleus for the development of a selfnourishing icecap that ultimately filled tha lake basin and overflowed its rim. This conclusion is based on several lines of evidence (RICHMOND and Pierce 1968):

(a) Some tributary valleys east of the lake contain erratics of igneous rock derived from the headwaters of the Yellowstone River.

(b) The lower ridges and valley slopes of the Absaroka Range are not grooved and scoured in a westerly direction as would be expected if valley glaciers had flowed west across them. Rather, they are only slightly modified and are covered by a thin veneer of glacial rubble, mostly locally derived.

(c) The till in many valleys east and south of the lake overlies gravel or lake silt deposits in proglacial lakes dammed by ice in the lake basin and then overridden by it.

(d) Very few erratics from the Absaroka Range occur west of the lake basin, and no erratics from the rhyolitic volcanic plateau west of the basin occur on its eastern slopes.

(e) Fragments of silicified lake silt and sand of Bull Lake age, derived from deposits beneath Pinedale Till along the north shore of the lake, are abundant in Pinedale Till to the north.

Gradually the ice in the lake basin thickened and when the upper valley of the Yellowstone River had been filled to a depth of nearly $800 \mathrm{~m}$ the ice overflowed westward across the Two Ocean Plateau (Figure 2). Here it scoured small lake basins elongate parallel to the direction of ice movement, rounded off the crests of cirques marginal to the plateau, and deposited a thin glacial rubble containing erratics of basalt, derived from the Absaroka Range to the east, on the plateau surface. West of the Two Ocean Plateau the ice flowed south into the drainage of the Snake River, where it was 300 to $325 \mathrm{~m}$ thick and its erosive effects, in the form of streaming, grooving, and molding of the landscape, are very marked.

Along the east side of Yellowstone Lake, the icecap ultimately attained a thickness of about $925 \mathrm{~m}$ and overflowed eastward across the crest of the Absaroka Range. Many summits were shaped by the ice into large roches moutonées oriented to east, and the normally sharp crests of cirque headwalls were rounded by the eastward overriding ice. A few erratics of rhyolite tuff, from the lower west slopes of the range, occur on and east of the crest. 


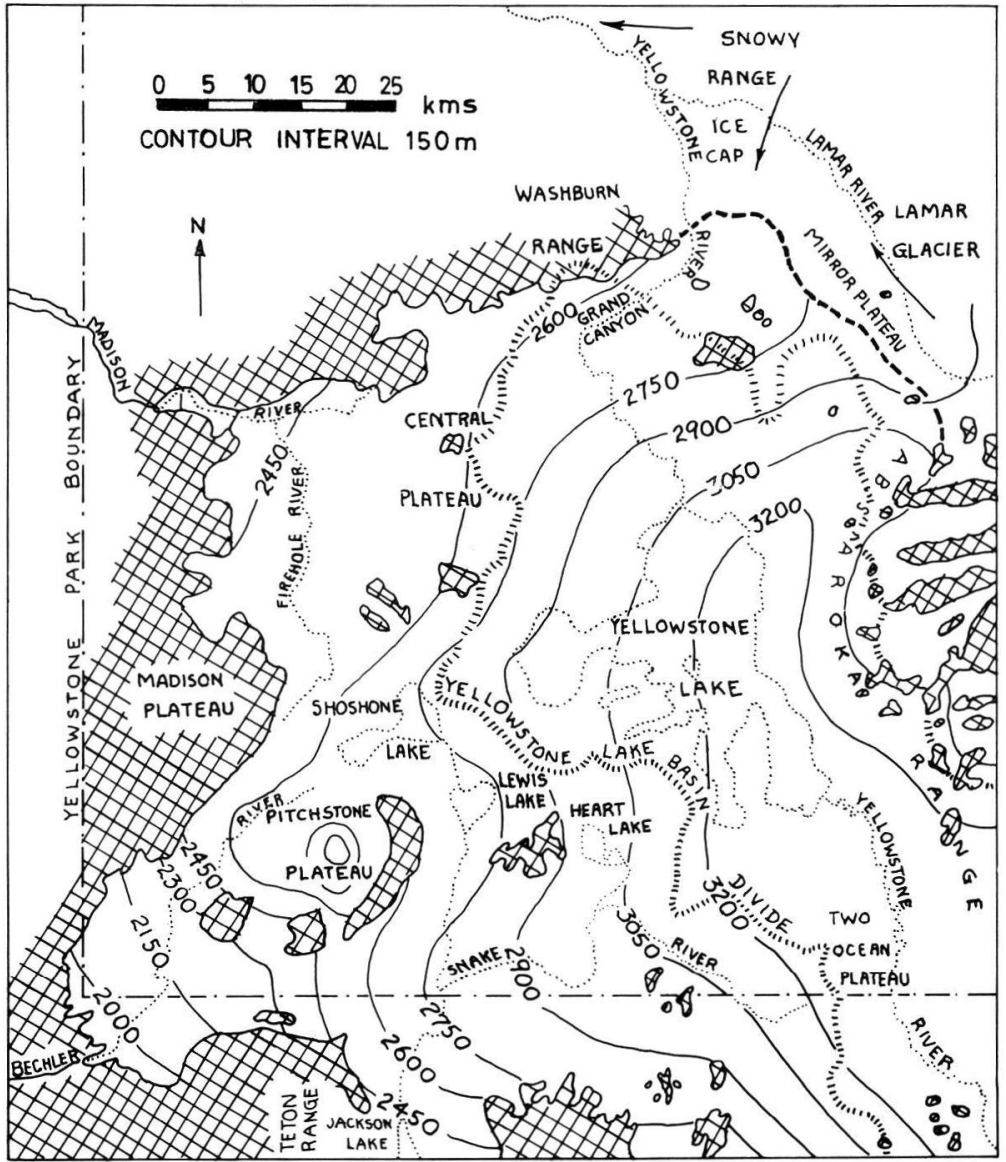

Fig. 2. Map showing maximum extent, inferred surface contours and areas projecting above surface of last Pleistocene ice cap in the Yellowstone Lake Basin.

Northeast of the lake basin, about 6 to $8 \mathrm{~km}$ north of the basin rim, the icecap came in contact with the Lamar Glacier (Figure 2). From here the boundary of the icecap extended northwestward, across the Grand Canyon of the Yellowstone River, and along the south flank of the Washburn Range. In these areas the ice was about $150 \mathrm{~m}$ thick.

West of the lake basin, the ice overflowed the crest of the Central Plateau, where it probably was only about $100 \mathrm{~m}$ thick, crossed the geyser basins along the Firehole River to the west and overlapped the margin of the Madison Plateau.

Southwest of the lake basin, the ice overflowed the drainage divide and filled the basins of Shoshone and Lewis Lakes to a depth of about $300 \mathrm{~m}$. From Shoshone Lake the ice extended southwest across the saddle separating the Pitchstone and Madison Plateaus and down the drainage of the Bechler River, where it was considerably augmented by ice from a local cap on the Pitchstone Plateau. From Lewis Lake, the ice flowed south and joined a larger mass which extended southwest from the Yellowstone Lake basin across high mountains in the south-central part of the Park and down the drainage of the Snake River. Spectacular glacial grooves occur on several of the summit ridges. In deep valleys separating the high mountains the ice was over $520 \mathrm{~m}$ thick, but in the valley of the Snake River at the Park boundary, it was only about $300 \mathrm{~m}$ thick. Part of this ice flowed south 
and joined glaciers from the Teton Range to form a large piedmont glacier in the basin of Jackson Lake; another part flowed west, along the south side of the Pitchstone Plateau, to join the tongue flowing around the north side of the plateau and terminate in a broad irregular arc just southwest of the Park. This ice was also considerably augmented by ice from the local cap on the Pitchstone Plateau.

At the glacial maximum, the Yellowstone Lake Basin icecap covered an area of about $6,200 \mathrm{~km}^{2}$ (Figure 2) and comprised about $975 \mathrm{~km}^{3}$ of ice. Areas projecting above the ice include peaks above $3,000 \mathrm{~m}$ along the crest of the Absaroka Range and several summits between 2,500 and $3,000 \mathrm{~m}$ in the southern part of the Park and south of the Park boundary. Some highlands at about $2,700 \mathrm{~m}$ in the northern and western parts of the cap also projected above the ice.

\section{Stagnation of the Pinedale icecap}

Following the Pinedale glacial maximum, there began a complex history of downwasting, readvance, and final stagnation of the icecap (Richmond 1968a). At first, the thin western part of the cap downwasted and, as uplands were increasingly exposed, the ice separated into several stagnant masses around which extensive ice-contact fluvioglacial sand and gravel was deposited. At this time, the active ice front was at least 5 to $25 \mathrm{~km}$ from its former maximum position. This early recession was followed by a series of minor advances during which discontinuous end moraines, outwash gravel plains, and thick embankments of hummocky till were deposited. The maximum extent of these secondary readvances is shown in part in Figure 3. To the north, the ice was still in contact with the Lamar Glacier; to the northwest it terminated irregularly along the crest of the Central Plateau; to the southwest, it lay in the drainage of the Bechler River about $10 \mathrm{~km}$ from its former stand. To the south, it was still in contact with piedmont ice from the Teton Range in the basin of Jackson Lake.

Subsequent downwasting and stagnation of the cap, though continuous, may be divided into four phases on the basis of the altitudes of drainage outlets leading away from the ice, and the altitude and character of ice-marginal fluvioglacial deposits. For convenience, altitudes are expressed in terms of height above the present elevation of Yellowstone Lake $(2,360 \mathrm{~m})$. Features associated with each phase are shown on Figure 3.

$\mathrm{Ph}$ as e 1. - As the cap downwasted from its secondary advance, uplands increasingly projected through the ice and the Yellowstone Lake Basin divide (Figure 3) began to be exposed. Emergence of the high Two Ocean Plateau caused stagnation of ice to the southwest. Icemarginal fluvioglacial deposits in passes leading across the plateau show that meltwaters from thick active ice in the upper valley of the Yellowstone River flowed west through them onto stagnant ice. These passes, which range in altitude from $570 \mathrm{~m}$ to $400 \mathrm{~m}$ above present Yellowstone Lake, probably served as outlets for only a short time.

Ph a s 2. - After the ice had wasted below the level of the high passes across the Two Ocean Plateau most of the drainage was probably on the ice itself until lower sectors of the Yellowstone Lake Basin divide became exposed and the icecap was largely confined to the basin itself. Drainage outlets across the divide became numerous and icecontact fluvioglacial deposits formed extensively on the upper slopes of the basin. To the east, valley glaciers in the Absaroka Range separated from the cap and fluvioglacial deposits formed in the intervening valley sectors against stagnant ice downstream (Fig. 3). The highest of these deposits are from $280 \mathrm{~m}$ to $190 \mathrm{~m}$ above present Yellowstone Lake, and meltwaters flowed east through the lowest pass across the range (Figure 3). Northeast of the lake basin, meltwaters drained north onto the Lamar Glacier through passes $260 \mathrm{~m}, 217 \mathrm{~m}$, and $180 \mathrm{~m}$ above present lake level. Extensive kame terrace deposits formed 
in valley re-entrants, and laminated silts were deposited in an icemarginal lake, ancestral to Yellowstone Lake, that drained north through the pass $180 \mathrm{~m}$ above present lake level. The area of the Grand Canyon of the Yellowstone River was still covered with ice. West of the lake basin, ice-contact deposits along the lake basin divide lead west through outlets ranging from $225 \mathrm{~m}$ to $140 \mathrm{~m}$ above present lake level. One outlet leads southwest to kame terraces and lacustrine deposits formed against stagnant ice in the basins of Shoshone and Lewis Lakes. Along the divide south of Yellowstone Lake, a broad high kame $225 \mathrm{~m}$ above the present lake level marks an ice-enclosed drainage leading south across the divide onto stagnant ice in the basin of Heart Lake and the valley of the Snake River. In the upper valley of the Yellowstone River, kame terraces were formed along

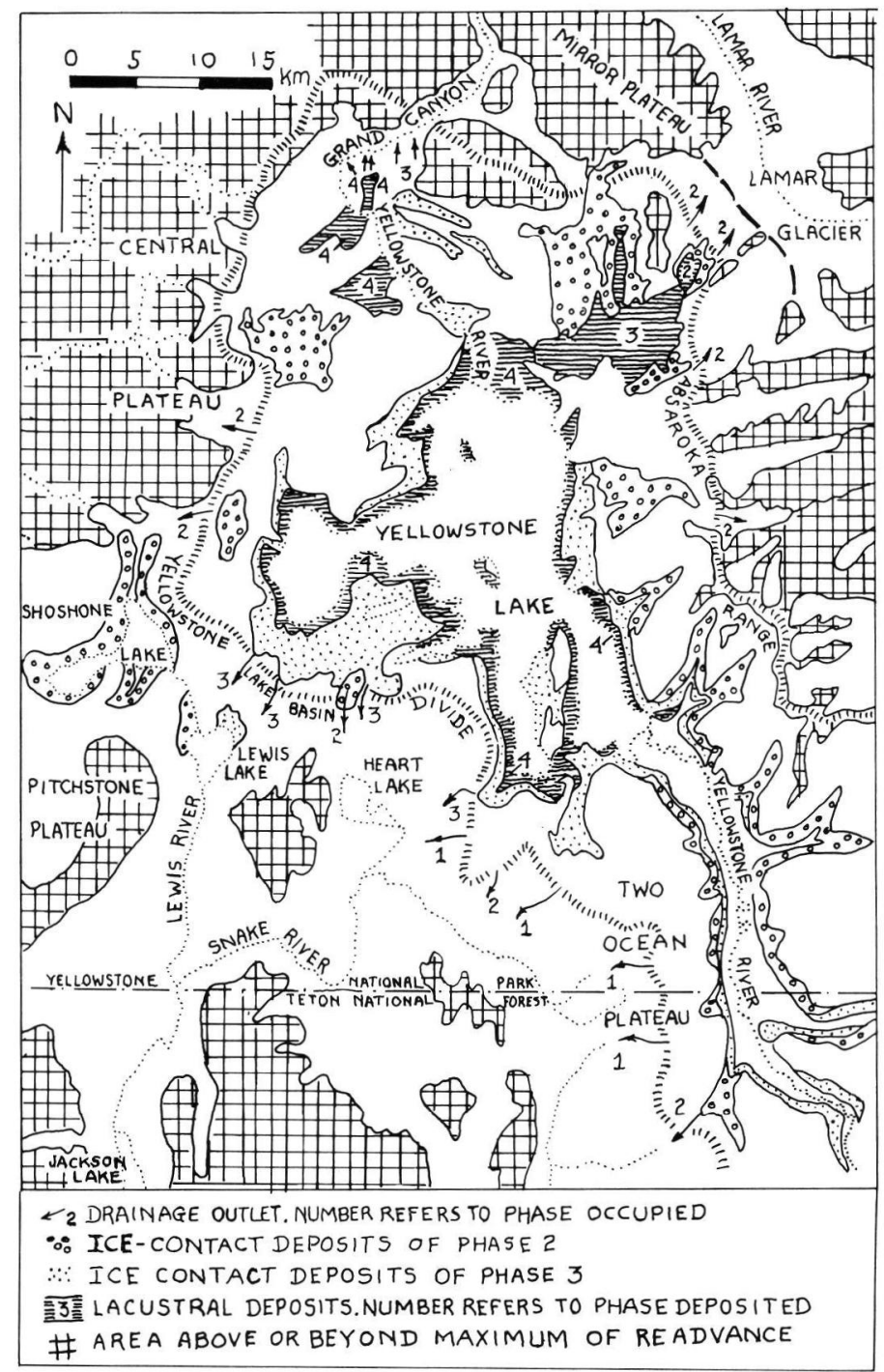

Fig. 3. Map showing maximum extent of secondary readvance of last Pleistocene icecap, and deposits and drainage outlets of its stagnation phases. 
the valley walls and in tributary re-entrants below an upper limit of $190 \mathrm{~m}$ above present Yellowstone Lake. Meltwaters drained west through the pass south of Two Ocean Plateau (Figure 3) until the ice wasted below this threshold, $115 \mathrm{~m}$ above present lake level.

Phase 3. - Further downwasting of the ice caused successively lower kame terraces to be deposited around the now totally stagnant ice mass in the basin. Drainage to the east, west, and onto the Lamar Glacier to the north had ceased. The last drainage across the divide to the south into the basin of Heart Lake was $76 \mathrm{~m}$ and the last into the basin of Lewis Lake was $67 \mathrm{~m}$ above present Yellowstone Lake. The oldest meltwater channel leading into the Grand Canyon of the Yellowstone River, which probably was still filled with ice, was $82 \mathrm{~m}$ above present Yellowstone Lake. Ancestral Yellowstone Lake continued to enlarge southwestward at gradually lower levels against the shrinking ice mass. Thick deposits of laminated silt between $115 \mathrm{~m}$ and $33 \mathrm{~m}$ above present lake level outline the extent of the lake during this phase. Similar deposits between $75 \mathrm{~m}$ and $33 \mathrm{~m}$ above present lake level occur in valley re-entrants along the east side of the lake basin. The absence of similar lacustral deposits on the west side of the basin suggests that the ice lingered against that slope in the shelter of the Central Plateau.

$\mathrm{Ph}$ a s e 4 . - The beginning of phase 4 is marked by a prominent terrace, $33 \mathrm{~m}$ above present lake level that extends essentially around the entire lake basin. An ice-marginal meltwater channel leads into the Grand Canyon (Figure 3) at the same height. This terrace shows that the remnant ice mass was entirely surrounded by at least a narrow band of water at this level. Similar but discontinuous terraces occur at $28 \mathrm{~m}$ and $24 \mathrm{~m}$ above present lake level. These terraces are locally kame terraces, made up of poorly sorted sand and silt, commonly covered by bouldery slumped till or solifluction debris and locally characterized by dead ice depressions. Elsewhere they are capped by beach deposits or lacustral silt formed in ice-marginal lakes. In a few places they are cut on rock.

In contrast are the characteristics of a widespread terrace about $21 \mathrm{~m}$ above present lake level that marks the end of phase 4. Its deposits (Figure 3) are commonly well-sorted sand and gravel. In places, these deposits are thin, are characterized by typical beach crossbedding, and rest on a bench cut into older fluvioglacial or lacustral deposits, or rock. Elsewhere, they form large spits and bars, characterized by steeply dipping foreset bedding, that could only have formed in a large body of open water subject to prevailing westerly winds and strong longshore currents. Although small dead ice depressions occur in deposits of this terrace at the south end of the lake, the development of the terrace on islands in the lake and the widespread distribution of the spits and bars clearly show that the icecap no longer existed. Final disappearance of the ice is believed to have been between 10,000 and 12,000 years ago.

If the Pleistocene ended about 11,000 years ago, the final disappearance of the icecap from the Yellowstone Lake Basin and the complete opening of Yellowstone Lake at a level $21 \mathrm{~m}$ higher than at present probably coincided with the beginning of Holocene time. The lake at the $21 \mathrm{~m}$ level may have been dammed at first by ice contact deposits and stagnant ice remnants in the valley of the Yellowstone River north of the lake. Subsequent lowering of the lake and the development of lower lake terraces at 14, 10, 8, 5 and $1.5 \mathrm{~m}$ above its present lavel have been controlled by erosion of hard lake silts of Bull Lake age at the outlet.

Holocene glaciation has been confined to cirques and valleys in the higher mountains, mainly east of the lake. Three groups of advances are recorded (RICHMOND 1968b). Moraines of the oldest advances (currently classified as late Pinedale) between 9,000 and 7,500 years ago reach an average lower altitude of about $2,600 \mathrm{~m}$. Those of the next youngest group of advances (Temple Lake Stade of Neoglaciation), about 3,700 to 950 
years ago, reach an average lower limit of about $2,875 \mathrm{~m}$, and those of the youngest group of advances (Gannett Peak Stade of Neoglaciation), about 400 years ago to the present, reach an average lower limit of about 2,975 m.

\section{References}

Boyd, F. R.: Welded tuffs and flows in the rhyolite plateau of Yellowstone Park, Wyoming. Geol. Soc. Amer. Bull., 72, 387-426, 1961.

Christiansen, R. L., Obradovich, J. D., and Blank, H. R., Jr.: Late Cenozoic volcanic stratigraphy of the Yellowstone Park region - a preliminary report (Abstract). - Geol. Soc. Amer., Rocky Mtn. Section, Program, 21st Ann. Mtg., 29-30, 1968.

Prostкa, H. J.: Facies of Eocene volcanics in northeastern Yellowstone National Park and their relations to eruptive centers (Abstract). - Geol. Soc. Amer., Rocky Mtn. Section, Program, 21st Ann. Mtg., 62-63, 1968.

Richmond, G. M.: Three pre-Wisconsin glacial stages in the Rocky Mountain region. - Geol. Soc. Amer. Bull., 68, 239-262, 1957.

- : Three pre-Bull Lake tills in the Wind River Mountains, Wyoming. - U. S. Geol. Surv. Prof. Paper 450-D, D132-D136, 1962.

- : Three pre-Bull Lake tills in the Wind River Mountains, Wyoming-a reinterpretation. - U.S. Geol. Survey Prof. Paper 501-D, D104-D109, 1964.

- : Glaciation of the Rocky Mountains, in The Quaternary of the United States, H. E. WRIGHT and D. G. Frey, editiors, Princeton Univ. Press, 217-230, 1965.

- : Stagnation of the Pinedale icecap in the Yellowstone Lake Basin, Wyoming (Abstract). Geol. Soc. Amer., Rocky Mtn. Section, Program, 21st Ann. Mtg., p. 65, 1968 [1968a].

- : Late Pinedale and Neoglacial Glaciation in the Absaroka Range, east of Yellowstone Lake, Wyoming (Abstract). - Geol. Soc. Amer., Rocky Mtn. Section, Program, 21st Ann. Mtg., 65-66, 1968 [1968b].

Richmond, G. M., and Pierce, K. L.: Late Pleistocene center of ice-accumulation over Yellowstone Lake area. In: Abstracts for 1967, Geol. Soc. Amer. Spec. Paper 115, p. 441, 1968.

Manuscript came in 2. 10. 1969.

Address of the author: Dr. G. M. Richmond, U. S. Geological Survey, Denver, Colorado 80225. 